\title{
ポンプ回路を用いたソフトスイッチング単相倍電圧整流器
}

\author{
正 員 伊藤 良三* 正員 石坂 耕一*
}

\section{Soft-Switched Single-Phase Voltage-Doubler Rectifier Using Pump Circuits}

Ryozo Itoh*, Member, Kouichi Ishizaka*, Member

\begin{abstract}
Soft-switched single-phase voltage-doubler rectifier using pump circuits is presented. The active power devices in the full-bridge resonant switch are allowed to turn on and off under zero-current switching (ZCS) and zero-voltage switching (ZVS) conditions, respectively. The switching transition is mainly governed by a series resonance. The experimental prototype employing two dual-switch power modules with insulated-gate bipolar transistors is implemented to investigate the operation under the pulse-width modulation. The experimental results confirm that the input current can be waveshaped sinusoidally with a near-unity power factor.
\end{abstract}

キーワード：単相整流器, 倍電圧, ソフトスイッチング, ポンプ回路, 正弦波入力電流

Keywords: single-phase rectifier, voltage-doubler, soft switching, pump circuit, sinusoidal input current

\section{1. まえがき}

ロスレススナバの機能を併せ持つ共振スイッチを用いる ことによって, 可制御素子がゼロ電流スイッチング (ZCS) でターンオン, ゼロ電圧スイッチング $(\mathrm{ZVS})$ でターンオフ する単相昇圧形整流器が実現できる ${ }^{(1)}$ 。本レターは, これと 等価な働きをするフルブリッジ構成の共振スイッチ(2) とポ ンプ回路を組み合わせたソフトスイッチング単相倍電圧整 流器を提案したものであり, パルス幅変調法としてチャー ジコントロール(3) を適用した実験から，入力電流をほとん ど力率 1 で正弦波状に制御できることを明らかにする。

\section{2. 主回路構成と動作原理}

図 1 に本レターで提案する単相倍電圧整流器を示す。共 振スイッチは，それぞれ $\mathrm{Q}_{1}, \mathrm{Q}_{2}, \mathrm{D}_{1}, \mathrm{D}_{2}$ および $\mathrm{Q}_{3}, \mathrm{Q}_{4}$, $\mathrm{D}_{3}, \mathrm{D}_{4}$ から成る 2 個の IGBT モジュールとインダクタ $\mathrm{L}_{\mathrm{r}}$, キャパシタ $\mathrm{C}_{\mathrm{r}}$ で構成される (2)。また，インダクタ $\mathrm{L}$ とキャ パシタ C は不連続なインダクタ電流 $\mathrm{i}_{\mathrm{r}}$ の高調波を減衰させ る低域通過フィルタとして動作し, $\mathrm{D}_{5} \sim \mathrm{D}_{8}$ は, 主に IGBT ターンオフ時におけるポンプ用キャパシタ $\mathrm{C}_{1 \mathrm{p}}, \mathrm{C}_{1 \mathrm{n}}$ の充放 電回路を確保するためのダイオードである。一方，図 2 は 電圧・電流制御ブロック図であり, 積分器, コンパレータお よび RS フリップフロップから成るチャージコントロール によって，スイッチング周期毎に $\left|\mathrm{i}_{\mathrm{r}}\right|$ の積分值に比例した電 荷 $\mathrm{q}$ が制御される。q の基準 $\mathrm{q}^{*}$ は予め ROM に書き込まれ た単位大きさの正弦全波整流信号と PI 制御器の出力の積に

\footnotetext{
* 福岡大学

干 814-0180 福岡市城南区七隈 8-19-1

Fukuoka University

8-19-1, Nanakuma, Jonan-ku, Fukuoka 814-0180
}

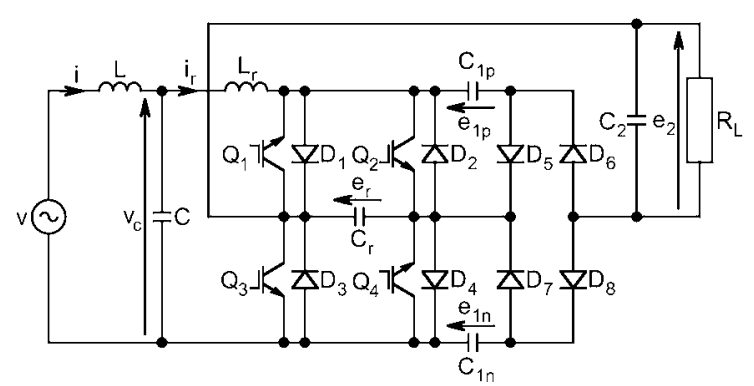

図 1 提案するソフトスイッチング単相倍電圧整流器 Fig. 1. Proposed soft-switched single-phase voltage-doubler rectifier.

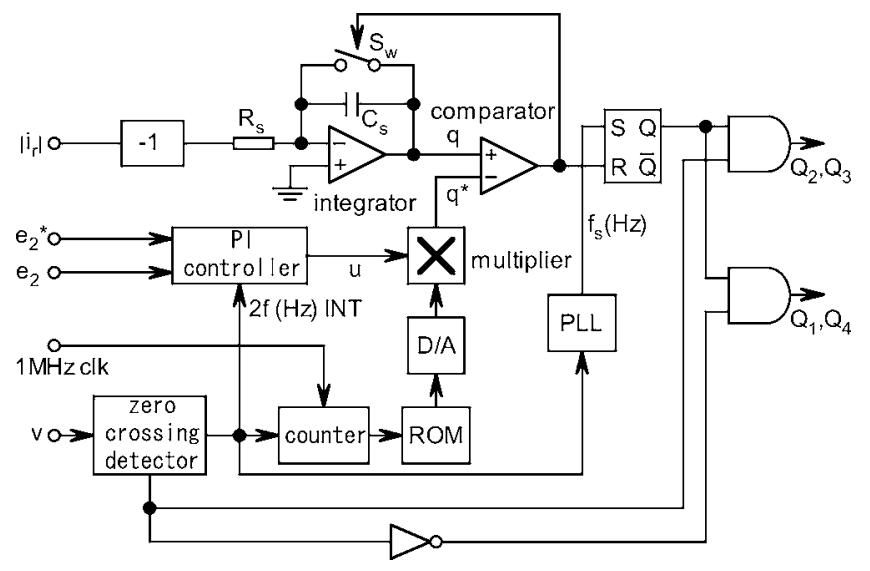

図 2 電圧・電流制御ブロック図

Fig. 2. Voltage and current control block diagram. 


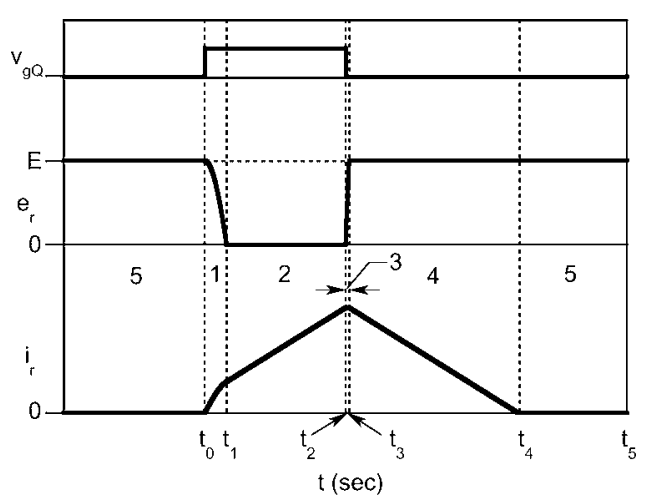

図 3 動作モード

Fig. 3. Modes of operation.

よって与えられ，その結果，各スイッチング周期の $\left|\mathrm{i}_{\mathrm{r}}\right|$ の時 間積分值が正弦波状に変化する。なお，fおよび $\mathrm{f}_{\mathrm{s}}$ は各々 電源周波数とスイッチング周波数であり, 出力電圧 $\mathrm{e}_{2}$ はそ の基準值 $\mathrm{e}_{2}^{*}$ 変えることにより調整される。ここで, $\mathrm{C}_{1 \mathrm{p}}$, $\mathrm{C}_{1 \mathrm{n}}, \mathrm{C}_{2}$ が十分大きいとすると, 各キャパシタの電圧は一 定と仮定でき，回路の対称性並びに後述するモード 4 の動 作から $\mathrm{e}_{1 \mathrm{p}}=\mathrm{e}_{1 \mathrm{n}}, \mathrm{e}_{1 \mathrm{p}}=\mathrm{e}_{2}-\mathrm{e}_{1 \mathrm{n}}$ であるので, $\mathrm{e}_{1 \mathrm{p}}=\mathrm{e}_{1 \mathrm{n}}=\mathrm{e}_{2} / 2$ が成立する。したがって, 電源電圧 $\mathrm{v}$ が正での一スイッチ ング周期に扔ける動作モードは, $\mathrm{e}_{1 \mathrm{p}}=\mathrm{e}_{\mathrm{ln}}=\mathrm{E}$ としたとき, 図 3 のように表すことができる。以下，簡単のため，低域 通過フィルタを無視し， $\mathrm{Q}_{2}, \mathrm{Q}_{3}$ にオンゲート信号 $\mathrm{v}_{\mathrm{gQ}}$ が 印加される $\mathrm{t}_{0}$ までは $\mathrm{i}_{\mathrm{r}}=0, \mathrm{e}_{\mathrm{r}}=\mathrm{E}>\mathrm{v}$ の状態にあるもの として動作モードの概略を説明する。

(1) $\mathrm{t}_{0}$ で $\mathrm{Q}_{2}, \mathrm{Q}_{3}$ にオンゲート信号が印加されると， $\mathrm{t}_{0}$ まで $\mathrm{i}_{\mathrm{r}}=0$ であったので, $\mathrm{Q}_{2}, \mathrm{Q}_{3}$ は ZCS でターンオンす る。その結果, $\mathrm{L}_{\mathrm{r}}$ と $\mathrm{C}_{\mathrm{r}}$ の直列共振によって $\mathrm{i}_{\mathrm{r}}$ が正弦波状 に増加し， $\mathrm{e}_{\mathrm{r}}$ は低下する。(2) $\mathrm{t}_{1}$ で $\mathrm{e}_{\mathrm{r}}=0$ になると, $\mathrm{D}_{1}$, $\mathrm{D}_{4}$ がターンオンする。したがって， $\mathrm{i}_{\mathrm{r}}$ は $\mathrm{D}_{1}-\mathrm{Q}_{3}$ と $\mathrm{Q}_{2}-\mathrm{D}_{4}$ の枝に分流し， $\mathrm{v} / \mathrm{L}_{\mathrm{r}}$ に比例して直線的に増加する。一方， $\mathrm{e}_{\mathrm{r}}$ は 0 に保たれる。(3) $\mathrm{q}$ が $\mathrm{t}_{2}$ で $\mathrm{q}^{*}$ に達すると， $\mathrm{Q}_{2}, \mathrm{Q}_{3}$ のオンゲート信号が遮断される。 $\mathrm{t}_{2}$ まで $\mathrm{e}_{\mathrm{r}}=0$ であったの で, $\mathrm{Q}_{2}, \mathrm{Q}_{3}$ は ZVS でターンオフする。このとき, $\mathrm{i}_{\mathrm{r}}$ は $\mathrm{D}_{1}$, $\mathrm{D}_{4}$ を通って流れ， $\mathrm{L}_{\mathrm{r}}$ と $\mathrm{C}_{\mathrm{r}}$ の直列共振によってピーク值に 至る。また， $\mathrm{e}_{\mathrm{r}}$ は $\mathrm{i}_{\mathrm{r}} / \mathrm{C}_{\mathrm{r}}$ に比例して上昇する。(4) $\mathrm{t}_{3}$ で $\mathrm{e}_{\mathrm{r}}$ が $\mathrm{E}$ に達すると $\mathrm{D}_{5}, \mathrm{D}_{8}$ が導通を開始する。したがって， $\mathrm{i}_{\mathrm{r}}$ は, $\mathrm{C}_{1 \mathrm{p}}-\mathrm{D}_{5}-\mathrm{D}_{4}$ と $\mathrm{D}_{1}-\mathrm{C}_{2}-\mathrm{D}_{8}-\mathrm{C}_{1 \mathrm{n}}$ に分流しながら，(v-E)/ $\mathrm{L}_{\mathrm{r}}$

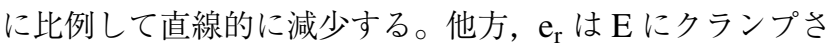
れる。(5) $\mathrm{t}_{4}$ で $\mathrm{i}_{\mathrm{r}}$ が 0 になると, 導通状態にあった総ての ダイオードがターンオフし，再び $\mathrm{Q}_{2} ， \mathrm{Q}_{3}$ にオンゲート信 号が印加される $\mathrm{t}_{5}$ まで $\mathrm{i}_{\mathrm{r}}=0, \mathrm{e}_{\mathrm{r}}=\mathrm{E}$ が維持される。モー ド 5 は, $\mathrm{Q}_{2}, \mathrm{Q}_{3}$ にオンゲート信号が印加される前の状態に 等しく，スイッチング周期毎にモード 1 からモード 5 の動 作が繰り返される。なお， $\mathrm{v}<0$ のときの動作は， $\mathrm{Q}_{2}$ およ び $\mathrm{Q}_{3}$ の役割を各々 $\mathrm{Q}_{1}$ と $\mathrm{Q}_{4}$ に置き換えて考えればよい。

\section{3. 実験結果}

本レターでは, 回路定数を $\mathrm{L}=1.36 \mathrm{mH}, \mathrm{C}=6 \mu \mathrm{F}, \mathrm{L}_{\mathrm{r}}$

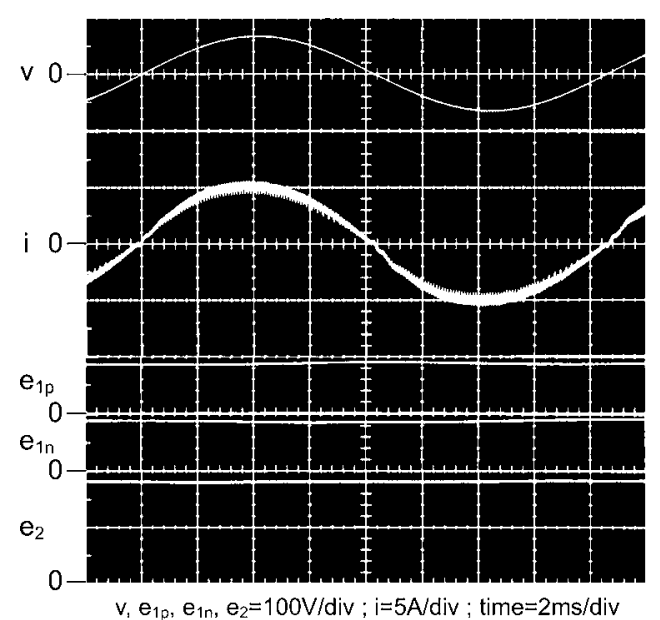

図 4 実測動作波形

Fig. 4. Experimental operating waveforms.

$=19.8 \mu \mathrm{H}, \quad \mathrm{C}_{\mathrm{r}}=0.1 \mu \mathrm{F}, \quad \mathrm{C}_{1 \mathrm{p}}=\mathrm{C}_{1 \mathrm{n}}=\mathrm{C}_{2}=2200 \mu \mathrm{F}, \quad \mathrm{R}_{\mathrm{L}}=$ $198 \Omega, \mathrm{R}_{\mathrm{s}}=1.8 \mathrm{k} \Omega, \mathrm{C}_{\mathrm{s}}=2200 \mathrm{pF}$ とし, 電源電圧 $\mathrm{V}=50 \mathrm{~V}$ $(\mathrm{f}=60 \mathrm{~Hz}), \mathrm{f}_{\mathrm{s}}=10.02 \mathrm{kHz}$ に設定して実験を行った。図 4 は, 出力電圧 $\mathrm{e}_{2}$ の平均值が $180 \mathrm{~V}$ となるように $\mathrm{e}_{2}^{*}$ を調整し たときの実測動作波形を示し, 入力電流 $\mathrm{i}$ の実効值は $3.97 \mathrm{~A}$ である。図より，入力電流はほほ力率 1 で正弦波状に制御 されていることがわかる。ちなみに，入力電流歪みの主な 原因となる低次高調波成分の基本波に対する割合は，FFT アナライザによる実測から，第 3 次，5次，7 次，9次，11 次, 13 次の順に各々 $3.752 \%, 1.300 \%, 0.671 \%, 0.580 \%$, 0.348\%，0.340\%であった。また，このときの実測総合歪み 率（THD）は 4.146\%，実測総合力率は 0.995 であった。

4. あとがき

以上，フルブリッジ構成の共振スイッチとポンプ回路を 組み合わせたソフトスイッチング単相倍電圧整流器を提案 し，ほとんど力率 1 の正弦波入力電流が得られることを示 した。今後，シミュレーションから実験結果の検証を行う 予定である。最後に，本研究の装置作成および実験に協力 された福岡大学大学院博士課程前期学生樋口義隆君に紙面 を借りて深謝する。

(平成 17 年 11 月 16 日受付)

\section{文献}

(1) N. Kimura, T. Morizane, and K. Taniguchi: "Analysis of PFC Boost Converter with Soft-Switching Configuration", T. IEE Japan, Vol.119-D, No.5, pp.617-627 (1999-5) (in Japanese)

木村紀之・森實俊充・谷口勝則 : 「ソフトスイッチング単相昇圧形 力率改善コンバータの特性解析と高調波抑制」, 電学論 D, 119, 5, pp.617-627 (1999-5)

(2) R. Itoh, K. Ishizaka, H. Kiyotake, and H. Okada: "Soft-Switched SinglePhase Boost Rectifier Using Full-Bridge Resonant Switch", IEE Electronics Letters, Vol.38, No.16, pp.843-844 (2002-8)

(3) K. Wang, D. Boroyevich, and F.C. Lee: "Charge Control of Three-Phase Buck PWM Rectifiers", IEEE Applied Power Electronics Conference, pp.824-831 (2000-2) 